\title{
Effect of Time Nitrogen Fertilizer Application on Growth and Yield of Grain Sorghum
}

\author{
U.N. Alse, P.O. Bhutada* and S.P. Mehtre \\ All India Co-ordinate Sorghum Research Project, Sorghum Research Station VNMKV, \\ Parbhani, India \\ *Corresponding author
}

Ke y w o r d s
$\begin{aligned} & \text { Nitrogen time of } \\ & \text { application, } \\ & \text { Sorghum, Nitrogen } \\ & \text { method of } \\ & \text { application }\end{aligned}$
Article Info
Accepted:
10 April 2019
Available Online:
10 May 2019

\section{A B S T R A C T}

\begin{abstract}
A study was established for determining the effect of nitrogen (urea) fertilizer method and time of application on the growth and yield of grain sorghum varieties. The experiment was conducted as a Factorial Randomized Block Design replicated thrice comprising five Nitrogen split doses with two varieties during 2014-15 growing season at sorghum research station VNMKV, Parbhani. The main plots were allocated to two genotype G1: CSH 16 \& G2: CSV 20 and the subplots were assigned to fertilizer application time viz., $\mathrm{N} 1: 50 \% \mathrm{~N}$ at sowing and $50 \%$ at $30 \mathrm{DAS}, \mathrm{N} 2: 50 \%$ at sowing $+25 \%$ at $30 \mathrm{DAS}+25 \%$ at boot-leaf stage (BLS), N3: $25 \%$ at sowing $+50 \%$ at 30 DAS $+25 \%$ at Boot leaf stage (BLS), N4: $25 \%$ at sowing $+50 \%$ at $30 \mathrm{DAS}+15 \%$ at BLS $+10 \%$ at grain filling stage (GFS), N5: $25 \%$ at sowing $+45 \%$ at $30 \mathrm{DAS}+5 \%$ at foliar spray at 45 DAS $+15 \%$ BLS $+10 \%$ at GFS. The results of the experiment revealed that time of $\mathrm{N}$ fertilizer application i.e. $25 \%$ at sowing $+50 \%$ at $30 \mathrm{DAS}+25 \%$ at Boot leaf stage (BLS ) gives higher grain and fodder yield over the other treatments. Among genotypes CSH 16 (2982 kg/ha) produced significantly the highest grain yield and fodder yield was significantly higher with CSV 20 (11373 kg /ha) over CSH-16.
\end{abstract}

\section{Introduction}

Sorghum (Sorghum bicolor (L.) Moench) is a crop of world-wide importance and is unique in its ability to produce under a wide array of harsh environmental conditions (House, 1995). Sorghum is an important component in traditional farming systems in the semiarid tropics of Africa and Asia.

Plant nutrition is an important factor, which directly affects the growth, yield and quality of a crop. Soil contains many mineral nutrients, organic material and water, which are absorbed by plants. If any of these nutrients are deficient or not available in the soil, it affects crop development and a plant shows deficiency symptoms. Therefore, soil nutrient management is necessary for successful crop production. Most of the nutrients are absorbed by plants through their roots from the soil. Nutrient management includes the type of fertilizer to be applied, rate of application and method of application. Nitrogen is the essential element required for plant growth in relatively large amounts. 
However, deficiencies of nitrogen are common. Nitrogen deficiency can result in reduced dry matter, crude protein and grain yield (Jarvis, 1996; Ashiono et al., 2005). Soil nutrients become depleted due to leaching of nitrogen, soil erosion and removal by crops (Zobeck et al., 2000). In soils with good aeration nitrate $\left(\mathrm{NO}_{3}-\right)$ is the dominant form of available nitrogen in higher plants. Its absorption and pattern of distribution in different parts of a plant is very important. Nitrate that is not absorbed by plants may contaminate underground or surface water by nitrate leaching or soil erosion. Increasing Nitrogen Use Efficiency (NUE) in plants is considered as a major way to decrease nitrate accumulation and its leaching in the soil. $\mathrm{N}$ source and method of fertilizer application have been identified as factors influencing NUE, as well as the pathway of $\mathrm{N}$ loss from the soil-plant system (Raun and Johnson, 1998).

There is difference for NUE, among different sorghum hybrids. Genetic variation was observed for $\mathrm{N}$ utilization between early and late-maturity sorghum hybrids. Genotypic variation has been observed for utilization of absorbed $\mathrm{N}$ for biomass production and harvest index (Gardner et al., 1994). The best time of nitrogen fertilizer application will significantly improve both quantity and quality of crops as well as NUE (Almodares, 1996).

In a study for determination of suitable time of nitrogen fertilizer application for grain sorghum, it was concluded that, if plants are sown in proper time, three-phase distribution of nitrogen fertilizer has the best effect on total dry weight, protein and height of plants (Kohanmoo and Mazahery, 1995). Application of nitrogen fertilizer at eight-leaf growth stage is feasible and would be beneficial for sorghum (Khosla et al., 2000). Delaying $\mathrm{N}$ fertilization 40 days after sowing, rather than applying at sowing, increased dry matter and grain yield of sorghum (Joseph et al., 1997). Grain yield of corn was 10.5 and 11.2 $\mathrm{Mg} \mathrm{ha}{ }^{-1}$ for nitrogen fertilization at planting and six-leaf stage, respectively (Sainz Rozas et al., 2004).

\section{Materials and Methods}

An experiment was conducted during kharif 2014-15 at S.R.S. VNMKV Parbhani, in Factorial Randomized Block Design replicated thrice comprising five Nitrogen split doses with two varieties. The main plots were allocated to two genotype $\mathrm{G}_{1}$ : $\mathrm{CSH} 16$ \& $\mathrm{G}_{2}$ : CSV 20 and the subplots were assigned to fertilizer application time viz., $\mathrm{N}_{1}: 50 \% \mathrm{~N}$ at sowing and $50 \%$ at $30 \mathrm{DAS}, \mathrm{N}_{2}: 50 \%$ at sowing $+25 \%$ at $30 \mathrm{DAS}+25 \%$ at boot-leaf stage (BLS), $\mathrm{N}_{3}: 25 \%$ at sowing $+50 \%$ at 30 DAS $+25 \%$ at Boot leaf stage (BLS), $\mathrm{N}_{4}: 25 \%$ at sowing $+50 \%$ at 30 DAS $+15 \%$ at BLS $+10 \%$ at grain filling stage (GFS), $\mathrm{N}_{5}: 25 \%$ at sowing $+45 \%$ at 30 DAS $+5 \%$ at foliar spray at 45 DAS $+15 \%$ BLS $+10 \%$ at GFS. The gross and net plot size were $4.5 \mathrm{~m} \mathrm{X} 5.0 \mathrm{~m}$ and $3.6 \mathrm{X} 4.4 \mathrm{~m}$ respectively. The sorghum genotype $\mathrm{CSH}-16$ and $\mathrm{CSV}-20$ were sown on $10^{\text {th }}$ July, 2014 and harvested on $3^{\text {rd }}$ Nov. 2014.

The recommended plant protection schedule was followed. The crops were fertilized as per the treatments. Sorghum was sown with row spacing of $45 \mathrm{~cm}$ and seeds $12 \mathrm{~cm}$ apart on each row having seed rate 7.5 to $10 \mathrm{~kg}$ respectively as per genotype. Important physical and chemical characteristics of soil samples were determined in laboratory including soil texture clay in nature, low in organic carbon (0.58), pH-8.5, low in available nitrogen $(166.80 \mathrm{~kg} / \mathrm{ha})$ and medium in phosphorus $(19.80 \mathrm{~kg} / \mathrm{ha})$ and high in potassium $(358.50 \mathrm{~kg} / \mathrm{ha})$. Treatment details as below 


\section{Treatment details}

Main plot: $\mathrm{G}_{1}$ : CSH 16 \& $\mathrm{G}_{2}$ : CSV 20

Sub-plot: $\mathrm{N}$ application methods

$\mathrm{N}_{1}: 50 \% \mathrm{~N}$ at sowing and $50 \%$ at $30 \mathrm{DAS}$

$\mathrm{N}_{2}: 50 \%$ at sowing $+25 \%$ at 30 DAS $+25 \%$ at boot-leaf stage (BLS)

$\mathrm{N}_{3}: 25 \%$ at sowing $+50 \%$ at $30 \mathrm{DAS}+25 \%$ at Boot leaf stage (BLS)

$\mathrm{N}_{4}: 25 \%$ at sowing $+50 \%$ at $30 \mathrm{DAS}+15 \%$ at BLS $+10 \%$ at grain filling stage (GFS)

$\mathrm{N}_{5}: 25 \%$ at sowing $+45 \%$ at $30 \mathrm{DAS}+5 \%$ at foliar spray at $45 \mathrm{DAS}+15 \% \mathrm{BLS}+10 \%$ at GFS

\section{Results and Discussion}

Nitrogen Fertilizer time of application had a significant effect on growth and Grain and fodder yield (Table 1).

\section{Grain yield}

The splitting of $\mathrm{N}$ in three doses i.e. $25 \%$ at sowing $+50 \%$ at 30 DAS $+25 \%$ at Boot leaf stage (BLS) $(3015 \mathrm{~kg} / \mathrm{ha})$ produced significantly higher grain yield than rest of treatments, however it was at par with $\mathrm{N}_{5}$ and $\mathrm{N}_{4}$. This indicated that three splitting of nitrogen found significantly superior over two splitting.

Table.1 Grain and fodder yield, gross monetary returns, net monetary returns and benefit: cost ratio as influenced by various treatment

\begin{tabular}{|c|c|c|c|c|c|}
\hline Treatments detail & $\begin{array}{l}\text { Grain yield } \\
\text { (kg/ha) }\end{array}$ & $\begin{array}{l}\text { Fodder } \text { yield } \\
\text { (kg/ha) }\end{array}$ & $\begin{array}{l}\text { GMR } \\
\text { (Rs/ha) }\end{array}$ & $\begin{array}{l}\text { NMR } \\
\text { (Rs/ha) }\end{array}$ & $\begin{array}{l}\mathrm{B}: \mathrm{C} \\
\text { ratio }\end{array}$ \\
\hline \multicolumn{6}{|l|}{ N splitting } \\
\hline $\mathrm{N}_{1}: 50 \% \mathrm{~N}$ at sowing and $50 \%$ at $30 \mathrm{DAS}$ & 2053 & 7869 & 4731 & 11435 & 1.29 \\
\hline $\begin{array}{l}\mathrm{N}_{2}: 50 \% \text { at sowing }+25 \% \text { at } 30 \text { DAS }+ \\
25 \% \text { at boot-leaf stage (BLS) }\end{array}$ & 2683 & 9898 & 52379 & 22966 & 1.53 \\
\hline $\begin{array}{l}\mathrm{N}_{3}: 25 \% \text { at sowing }+50 \% \text { at } 30 \text { DAS } \\
+25 \% \text { at Boot leaf stage (BLS) }\end{array}$ & 3015 & 12068 & 61008 & 31808 & 1.71 \\
\hline $\begin{array}{l}\mathrm{N}_{4}: 25 \% \text { at sowing }+50 \% \text { at } 30 \text { DAS } \\
+15 \% \text { at BLS }+10 \% \text { at grain filling stage } \\
\text { (GFS) }\end{array}$ & 2834 & 11017 & 56505 & 26507 & 1.59 \\
\hline $\begin{array}{l}\mathrm{N}_{5}: 25 \% \text { at sowing }+45 \% \text { at } 30 \mathrm{DAS}+ \\
5 \% \text { at foliar spray at } 45 \text { DAS }+15 \% \text { BLS } \\
+10 \% \text { at GFS }\end{array}$ & 2791 & 10482 & 54883 & 24135 & 1.54 \\
\hline SE+- & 79 & 336 & 1963 & 1357 & 0.03 \\
\hline CD at $5 \%$ & 236 & 1008 & 5889 & 4071 & 0.09 \\
\hline \multicolumn{6}{|l|}{ Genotypes } \\
\hline $\mathrm{V}_{1}:$ CSH 16 & 2982 & 9160 & 58947 & 29516 & 1.66 \\
\hline $\mathrm{V}_{2}: \mathrm{CSV} 20$ & 2368 & 11373 & 47255 & 17224 & 1.41 \\
\hline SE+- & 50 & 213 & 1241 & 858 & 0.02 \\
\hline CD at $5 \%$ & 149 & 639 & 3723 & 2575 & 0.06 \\
\hline \multicolumn{6}{|l|}{ Interaction } \\
\hline SE+- & 112 & 476 & 2775 & 1919 & 0.04 \\
\hline CD at $5 \%$ & NS & NS & NS & NS & NS \\
\hline Grand mean & 2675 & 10267 & 53101 & 23370 & 1.53 \\
\hline
\end{tabular}


Table. 2 No. of panicles, 50\% flowering, physiological maturity, plant height and 100 seed weight as influenced by various treatments

\begin{tabular}{|c|c|c|c|c|c|}
\hline Treatments detail & $\begin{array}{l}\text { No. of } \\
\text { panicles } / \mathrm{m}^{2}\end{array}$ & $\begin{array}{l}50 \% \\
\text { flowering } \\
\text { (Days) }\end{array}$ & $\begin{array}{l}\text { Physiological } \\
\text { maturity } \\
\text { (days) }\end{array}$ & $\begin{array}{l}\text { Plant height } \\
(\mathrm{cm})\end{array}$ & 100 seed wt $(g)$ \\
\hline \multicolumn{6}{|l|}{ N splitting } \\
\hline $\begin{array}{l}N_{1}: 50 \% \mathrm{~N} \text { at sowing and } 50 \% \text { at } 30 \\
\text { DAS }\end{array}$ & 14 & 64 & 116 & 222 & 2.85 \\
\hline $\begin{array}{l}\mathrm{N}_{2}: 50 \% \text { at sowing }+25 \% \text { at } 30 \mathrm{DAS}+ \\
25 \% \text { at boot-leaf stage (BLS) }\end{array}$ & 14 & 64 & 116 & 226 & 3.00 \\
\hline $\begin{array}{l}\mathrm{N}_{3}: 25 \% \text { at sowing }+50 \% \text { at } 30 \text { DAS } \\
+25 \% \text { at Boot leaf stage (BLS) }\end{array}$ & 14 & 66 & 118 & 233 & 3.27 \\
\hline $\begin{array}{l}\mathrm{N}_{4}: 25 \% \text { at sowing }+50 \% \text { at } 30 \text { DAS } \\
+15 \% \text { at BLS }+10 \% \text { at grain filling } \\
\text { stage (GFS) }\end{array}$ & 14 & 66 & 118 & 232 & 3.17 \\
\hline $\begin{array}{l}\mathrm{N}_{5}: 25 \% \text { at sowing }+45 \% \text { at } 30 \text { DAS + } \\
5 \% \text { at foliar spray at } 45 \text { DAS }+15 \% \\
\text { BLS }+10 \% \text { at GFS }\end{array}$ & 13 & 65 & 117 & 228 & 3.10 \\
\hline SE+- & 0.13 & 0.40 & 0.40 & 1.22 & 0.25 \\
\hline CD at $5 \%$ & NS & 1.20 & 1.20 & 3.64 & NS \\
\hline \multicolumn{6}{|l|}{ Genotypes } \\
\hline $\mathrm{G}_{1}: \mathrm{CSH} 16$ & 14 & 64 & 116 & 184 & 3.32 \\
\hline$G_{2}: C S V 20$ & 14 & 66 & 118 & 272 & 2.83 \\
\hline SE+- & 0.04 & 0.25 & 0.25 & 0.77 & 0.11 \\
\hline CD at $5 \%$ & NS & 0.76 & 0.76 & 2.30 & 0.34 \\
\hline \multicolumn{6}{|l|}{ Interaction } \\
\hline SE+- & 0.19 & 0.57 & 0.57 & 1.73 & 0.25 \\
\hline CD at $5 \%$ & NS & NS & NS & NS & NS \\
\hline Grand mean & 14 & 65 & 117 & 228 & 3.08 \\
\hline
\end{tabular}

\section{Fodder yield}

The fodder yield was highest under treatment $\mathrm{N}_{3}(12068 \mathrm{~kg} / \mathrm{ha})$ than other nitrogen splitting. This might due to availability of nitrogen up to boot leaf stage.

\section{Genotypes}

\section{Grain yield}

Hybrid CSH 16 (2982 kg/ha) produced significantly the highest grain yield than CSV $20(2368 \mathrm{~kg} / \mathrm{ha})$. This might be due to genetic characteristic of genotypes.

\section{Fodder yield}

Fodder yield was significantly higher with CSV 20 (11373 kg/ha) as compared to CSH $16(9160 \mathrm{~kg} / \mathrm{ha})$, because variety produces higher fodder yield than hybrid.

\section{Economics}

The application of three split doses of $\mathrm{N}$ i.e. $25 \%$ at sowing $+50 \%$ at $30 \mathrm{DAS}+25 \%$ at boot leaf stage returned significantly higher gross returns (Rs. 61008/ha) except net (Rs.3108/ha) and B:C (1.71) ratio as compared to other treatments, it was significantly comparable with treatment $\mathrm{T}_{4}$. 
The genotype CSH 16 expressed significantly greater amount of gross (58947/ha), net (29516/ha) and B:C ratio (1.66) as compared to CSV 20, sowing to higher grain yield.

\section{Interaction}

Interaction effect found to be non significant.

\section{Ancillary data}

Three Split application of nitrogen i.e N3 recorded higher plant height and 100 seed weight over rest of treatment (Table 2)

In conclusion, nitrogen should be applied in three $\left(\mathrm{N}_{3}\right)$ split doses to kharif sorghum to produce higher grain and fodder yield. Hybrid $\mathrm{CSH} 16$ produces more grain than fodder yield recorded by CSV-20.

\section{References}

Almodares, A., 1996. Effect of genotype and nitrogen content on protein of grain sorghum. J. Res. Construct., 32: 6065.

Ashiono, G.B., S. Gatuiku, P. Mwangi and T.E. Akuja, 2005. Effect of nitrogen and phosphorus application on growth and yield of dual-purpose sorghum (Sorghum bicolor (L.) Moench), E1291, in the dry highlands of Kenya. Asian J. Plant Sci., 4: 379-382.

Gardner, J.C., J.W. Maranville and E.T. Paparozzi, 1994. Nitrogen use efficiency among diverse sorghum cultivars. Crop Sci., 34: 728-733.

House, L.R., 1995. Sorghum: One of the world's great cereals. Afr. Crop Sci. J., 3: 135-142. Jarvis, S.C., 1996. Future trends in nitrogen research. Plant Soil, 181: 47-56.

Joseph, J., Adu-Gyam Fi, O. Ito, T. Yoneyama, D. Gayatri and K. Katayama, 1997. Timing of N fertilization on $\mathrm{N}_{2}$ fixation, $\mathrm{N}$ recovery and soil profile nitrate dynamics on sorghum/pigeon pea intercrops on Alfisols on the semi-arid tropics. Nutrient cycl. Agroecosys., 48: 197208.

Kasmshita, A., S. Fukai, R.C. Muchow and M. Cooper, 1998. Sorghum hybrid differences in grain yield and nitrogen concentration under low soil nitrogen availability. II. Hybrids with contrasting phenology. Aust. J. Agric. Res., 49: 1277-1286.

Khosla, R., M.M., Alley and P.H. Davis, 2000. Nitrogen management in notillage grain sorghum production: I. Rate and time of application. Agron. J., 92: 321-328.

Kohanmoo, M., and D. Mazahery, 1998. Effect of nitrogen fertilizer distribution and irrigation period (time) on yield and protein of forage sorghum. Proceedings of the 5th Iranian Congress of Crop Production and Plant Breeding, August 31September 1, 1998, Karaj, Iran, pp: 311-.

Raun, W.R., and G.V. Johnson, 1999. Improving nitrogen use efficiency for cereal production. Agron. J., 91: 357-363.

Raun, W.R., G.V. Johnson, S.B. Phillips, and R.L. Westerman. 1998. and nitrogen use efficiency of six spring wheat (Triticum aestivum Effect of long-term $\mathrm{N}$ fertilization on soil organic $\mathrm{C}$ and total $\mathrm{N}$ L.) cultivars, in relation to estimated moisture supply. Can. J. Plant in continuous wheat under conventional tillage in Oklahoma. Soil Sci. 72:235-241. Tillage Res. 47:323330

Sainz Rozas, H.R., H.E. Echeverria and P.A. Barbieri, 2004. Nitrogen balanced as affected by application time and nitrogen fertilizer rate in irrigated no- 
tillage maize. Agron. J., 96: 16221631.

Zobeck, T.M., N.C. Parker, S. Haskell and K. Guoding, 2000. Scaling up from field to region for wind erosion prediction using a field-scale wind erosion model and GIS. Agric. Ecosyst. Environ., 82: 247-259.

\section{How to cite this article:}

Alse, U.N., P.O. Bhutada and Mehtre, S.P. 2019. Effect of Time Nitrogen Fertilizer Application on Growth and Yield of Grain Sorghum. Int.J.Curr.Microbiol.App.Sci. 8(05): 987992. doi: https://doi.org/10.20546/ijcmas.2019.805.115 